\title{
Improving Reading Comprehension Skills with Children's Books through Metacognitive Strategy: The Turkish Context
}

\author{
Erkan Çer ${ }^{1}$, Ertuğrul Şahin ${ }^{2}$ \\ ${ }^{1}$ Department of Turkish Education, Faculty of Education, Amasya University, Turkey \\ ${ }^{2}$ Department of Guidance and Psychological Counseling, Faculty of Education, Amasya University, Turkey \\ Correspondence: Erkan Çer, Department of Turkish Education, Faculty of Education, Amasya University, Turkey.
}

Received: May 24, 2016 Accepted: June 15, 2016 Online Published: June 24, 2016

doi:10.11114/jets.v4i9.1566 URL: http://dx.doi.org/10.11114/jets.v4i9.1566

\begin{abstract}
The aim of this study was to explore the effect of metacognitive strategy in improving reading comprehension skills through children's literature of literary quality. A quasi-experimental study was carried out in a private secondary school in a city located Middle Black Sea region of Turkey. Two classes were randomly chosen as the study group, and since the academic achievement scores of the students in these two classes were similar, one class was assigned as the experimental group and the other as the control group. There were 35 students in experimental group whereas while the control group consisted of 30 . The results of the study were analyzed using independent t-test samples to determine if there was a significant difference in reading comprehension skills during the pre-test and the post-test between the experimental and the control group. Moreover, One Way Ancova analysis was used to determine the effect of metacognitive strategy on improving reading comprehension skills in books of literary quality. According to the results of t-test analysis, there was a significant difference of between the experimental and the control group in reading comprehension skills. As a result of One Way Ancova analysis, a significant difference was found between the pre-test and the post-test in the experimental group. Thus, when students used metacognitive strategy in books of literary quality, they obviously advanced in terms of their reading comprehension. This fact suggests that using metacognitive strategy in books of literary quality helped students in the experimental group improve both their reading skills and reading comprehension skills, when compared to the control group, in which an attempt was made to improve reading and comprehension skills in the conventional way.
\end{abstract}

Keywords: metacognitive strategy, reading comprehension, children's books, quasi-experiment

\section{Introduction}

Secondary school years represent a significant transition period for most Turkish adolescents. In addition to experiencing enormous changes in their bodies, most struggle with building moral rules and values, trying to be a contributing member of society, establishing an independent personality, preparing for an important exam, establishing new friendships, transitioning to a new school, and entering puberty (Şahin, Barut, \&Ersanl, 2013a, 2013b; Şahin, Barut, Ersanlı, \& Kumcağız, 2014; Şahin, Ersanlı, Kumcağız, Barut, \& Ak, 2014; Şahin \&Topkaya, 2015). A possible way for Turkish adolescents to effectively cope with these challenging tasks may be to develop their reading skills. The purpose of this study is to examine the effectiveness of an intervention that aims to improve reading compheresion of first year secondary school students.

Improving reading comprehension skills is based on qualified interactions performed by language (Aslan, 2007a; Dickinson \& Porche, 2011; Spear-Swerling, Brucker, \& Alfano, 2010). The focus of these interactions should be books of literary quality, which are appropriate for the children's developmental levels, prepared with artistic sensitivity, and respond to the needs and interests of children (Çer, 2016a, 2016b; Dilidüzgün, 2004; Neuman \& Wright, 2007; Sawyer, 2012; Sever, 2008). In addition, metacognitive strategy should be used to improve reading comprehension skills (Eiles \& Pinkley, 2006). Thus, during the reading process, the child should also be able to engage in planning (Dutta, 1995), self-monitoring (Schunk, 1997; Zimmerman, 1995), self-assessment (Benson, 2001), and self-regulation (Baker, 2002; Kuhn, 2000; O'Malley \& Chamet, 1990).

By using metacognitive strategy while students' comprehension and intellectual skills are improved in pre-, during- and post-reading, they may become successful participants who are active in terms of attitude, knowledge, motivation, and 
expectations (Alexander \& Jetton, 2000). Furthermore, they may improve their vocabulary while reflecting emotions and thoughts efficiently (Boulware-Gooden, Carreker, Thornhill, \& Joshi, 2007). All these skills reveal the significance of metacognitive strategy in reading comprehension (Kuhn, 2000). In this respect, the student is supposed to use metacognitive strategy, including all processes of reading, together with appropriate books for his developmental level, so that he can become a good reader. Thus, the child may improve his reading comprehension skills and express his emotions and thoughts more effectively.

While developing reading ability is important, social and cultural influences in literary works that might affect children's social, personal, and emotion development must be considered. In Turkey, the program that aims to improve reading and reading comprehension skills is carried out through a reading list called the 100 Basic Works prepared by the Ministry of Education (Ministry of Education, 2005). This list contains classical works from world literature, such as The Coure by Edmondo de Amicis, The Happy Prince by Oscar Wilde, Oliver Twist by Charles Dickens, Treasure Island by Robert Louis Stevenson, The Pinocchio by Carlo Collodi, My Sweet Orange Tree by Jose Mauro de Vasconcelos, and those from the Turkish literature, such as Yalnız Efe by Omer Seyfettin, Seçme Hikayeler by Sait Faik Abasiyanık, Falaka by Ahmet Rasim, and Vatan Yahut Silistre by Namık Kemal. However, some researchers suggest that the program presented with these books does not have the qualifications to help children improve their reading and reading comprehension skills (Dilidüzgün, 2006) on grounds that, rather than aiming to improve reading comprehension skills, the values, traditions, and customs belonging to Turkish culture and the passive child profile found in classics of world literature were prioritized in the preparation of this book list. Thus, children reading these books are expected to be made passive stereotyped nationalists (Çer, 2015). Moreover, translating formulaic expressions such as "Oh my God" "I hope that" and "for God's sake" in Carlo Collodi's Pinocchio and Johanna Spyri's Heidi as "oh my Allah" (for oh my God) "inshallah" (for I hope that) and "for Allah's acceptance" (for God's sake) also shows that this list prioritizes the Islamic formulaic expressions rather than corresponding to the Christian formulaic expressions (Kansu-Yetkiner, 2014).

Secondly, this book list cannot help children in Turkey developed the love for and habit of reading (Dilidüzgün, 2006; Children's Foundation, 2009), which is evidenced by the $18 \%$ reading ratings of the books in this list (Ar1 \& Okur, 2013). Most characters in these books are also associated with passive, vague, non-dynamic, and limited roles. All these conditions may cause the child to avoid reading and negatively affect his reading comprehension (Aslan, 2010; Çer, 2015; Sever, 2006).

Thirdly, the Ministry of Education has made the reading of these books compulsory under the title of "reading hours" which were fixed at 30 minutes in primary schools in Turkey (Ministry of Education, 2008). In these reading classes with no reading strategies, students reluctantly engage in silent reading. Students can neither read enough nor find the strategies to improve reading comprehension in these hours when they are not employing metacognitive reading (Köksal \& Değirmenci, 2015). Therefore, children's attitudes and reading comprehension more likely to not advance (İşcan, Arıkan, \& Küçükaydın, 2013). Another figure also showed that Turkey was 37th in 2006, 41st in 2009, 42nd 2014, and 41st in 2015 in reading comprehension clearly proves this to be true (OECD, 2006, 2010, 2014, 2016).

Finally, there has been a number of study on reading comprehension and metacognitive fields (Başaran, 2013; Bozkurt \& Memiş, 2013; Çakıroğlu \& Ataman, 2008; Mert, 2015). After an overview of this research, it was clear that the deficiency lies in the fact that the texts used with metacognitive strategy were either related to the 100 Basic Works or they were unsuitable texts found in course books. Reading classes should be conducted with books created by an artist, which arouse higher-order thinking, and in turn children can find their own developmental reality, instead of books that do not help improve reading comprehension skills. Hence, this article may also present significant contributions to the literature since its goals is to help discover the usefulness of metacognitive strategy and books of literary quality, which should be appropriate for the developmental levels of children. This can both help children improve their reading comprehension skills and become aware of how they will use books suitable for their own developmental levels. In addition, this article proposes that the concept "strategy" be included in the relationship between the child and the book as the "third dimension" in terms of quality and level, while helping improve reading comprehension skills.

\subsection{Reading Comprehension and Metacognitive Strategy}

Reading is composed of a series of complex actions, related to physiological, psychological, psycholinguistic, social, affective, cognitive, and metacognitive processes, in reconstructing foreknowledge, in analyzing the meaning of words, in monitoring the text, and in inferring the gist and meta structure of the text (Adam, 1990; Andorsen, 1994; Small \& Arnone, 2011). Reading is based on coordinating the processing of various affective and cognitive components, such as seeing, attention, focusing, perception, recalling, building relations, analyzing, and interpretation. It is a sophisticated process with physiological, cognitive, and spiritual sides, such as grasping, analyzing, and evaluating emotions and thoughts within the text (Cain, Oakhill, \& Bryant, 2004) and a cognitive activity based on receiving, conceptualizing, grasping, and interpreting the words via the sense organs. The main purpose of cognitive, metacognitive, and affective 
activities yielded by reading is to make inferences from the text (Sweet \& Snow, 2002).

The reader, by comprehending what he reads, interactively tries to reflect what is told in the text by associating his foreknowledge with it (Meneghetti, Carretti, \& De Beni, 2006). Through this process, several cognitive, metacognitive, motivational, and affective relations appear between the reader and the text (Guthrie, Wigfield, Metsala, \& Cox, 1999). While perception, comprehension, recalling, grasping, etc. appear in the cognitive aspect, planning, monitoring, analyzing, synthesizing, evaluating, questioning, self-regulation, inferring, estimating, etc. appear in the metacognitive sense (O'Malley \& Chamot, 1990). Motivation is another important variable in conceptualizing the text because during the reading process, since there is no random inference from the text, all these actions are performed through purposeful and eager concentration on the text. In particular, intrinsic motivation, self-sufficiency, interest, purpose, and beliefs are important motivational variables in reading comprehension (Guthrie \&Wigfield, 2000). Moreover, the reality (his nature, interest, need, perspective, language, and cognitive capacity) in which the reader resides while grasping the text, and the reflection of this reality in the text, may also help to shape the meaning (Çer, 2016b, 2016c; Sever, 2008).

Metacognitive strategy encompasses planning, self-monitoring, self-evaluating, and self-regulating processes in pre-, during-, and post-reading (Pressley \& Afferbach, 1995; O'Malley \& Chamot, 1990) and evolves from cognitive processes (Veeman, Van Hout-Wolters, \& Afflerbach, 2006). This situation not only enhances the power of behavior and imagination of the child (Staton, 1984), but it also improves critical thinking (Davidson, 1994), learning about learning, becoming aware of cognitive processes (Anderson, 2002), and creative thinking (Wang, 2011). In addition, while the reading frequency of children with metacognitive strategy improves their reading skills (Leppanen, Aunola, \&Nurmi, 2005), it also contributes to their comprehension levels, vocabulary, general knowledge levels, attitudes, and behaviors (Tan \& Nicholson, 1998). In other words, as the reading skills of a student with metacognitive strategy improve, his metacognitive skills, including perception, grasping, sensing, discerning, synthesizing, analyzing, and evaluating; aesthetic and sensual skills, such as admiration and taste; and personal attitudes and skills, such as selection, decision making, self-perception, and self- sufficiency can also improve (Senechal, LeFevre, Hudson, \& Lawson, 1996). Within reading culture, such a conception is required so that thinking, sensitive, and participating individuals can have a place in society. Thus, the reader will not only be satisfied merely with his reading comprehension and grasping skills but also improve his higher-order thinking skills.

\subsection{Works of Children's Literature}

One of the important variables determining comprehension skills is works of children's literature in which children interact with visual and linguistic texts (Saxby, 2007; Lukens, Smith, \& Coffel, 2013). In other words, it has been observed that children who begin interacting with works of artistic quality develop comprehension and expression skills efficiently (Sever, 2008) because this process makes children contemplate how language works. In this respect, works of children's literature should exist in children's lives as an effective stimulus that is part of reality since the most competent usage of a language is found in texts of literary quality. Poems, novels, and short stories that make the power of intuition and sensation concrete reflect the beauty of expression of the society to which they belong. Thus, the child who interacts and communicates with the text can improve his cognitive, metacognitive, linguistic, affective, social, and personal skills by being inspired by the expressional attributes of his own language.

Children's literature of literary quality is required to make cognitive and metacognitive skills appear because one of the most important functions of works of children's literature is to support their cognitive, individual, and social development by helping them achieve higher-order thinking (Aslan, 2007b; Sawyer, 2012; Sever, 2008; Russell, 2009). Hence, the relationship the child establishes using a visual or a linguistic text is shaped in the cognitive and metacognitive processes such as perceiving, comprehending, grasping, discerning, comparing, associating, evaluating, and selecting. Thus, the child inclines to his metacognitive skills while he tries to extrapolate from works of literary quality. This inclination not only expands the child's intellectual limits but also advances his relationship with the book; however, children who have not encountered enough books of literary quality, which are supposed to be appropriate for their developmental level and who consequently have not advanced in reading skills through metacognitive strategy, were found to be inadequate at monitoring the text (Baker \& Brown, 1984), analyzing the text (Goswani \& Bryant, 1990), grasping the gist of the text (Stevens, 1988), defining the terms related to the text (Day \& Zajakowski, 1991), intrinsically concentrating on the text (Lau \& Chan, 2006), drawing conclusions (Long, Seely, Oppy, \& Golding, 1996), recognizing problems during reading (Cheng, 1993), and implementing processes of metacognitive awareness (Dole, Brown, \&Trathen, 1996). Thus, one of the most important reasons that children are unable to acquire the types of behavior at the top levels of cognitive processes is that they do not have qualified books and cannot read properly since they do not use the metacognitive strategy. Therefore, it is necessary to introduce books which are appropriate for children's developmental levels and then teach them how to use metacognitive strategy efficiently. 


\section{Method}

\subsection{Research Design}

A quasi-experimental design with a pre-test and post-test control group was used in this study. In quasi-experimental design with a pre-test and post-test control group, besides the experimental group tested by the independent variable, there is an additional group not affected by the independent variable. This design includes an experimental and a control group but participants are not randomly chosen. If there is no significant difference between the pre-test scores of the groups, groups may be said to be relatively equivalent. Varying points of both groups from the pre-test to the post-test are compared in order to determine if there is a significant difference or not, while testing the respondents (Christensen, 2004). To sum up, this study examined whether there was a significant difference in the reading comprehension skill scores between the control group, which had studied by conventional teaching and reading of the 100 Basic Works, and the experimental group, which used metacognitive strategy with children's books of literary quality.

\subsection{Participants}

This study was performed on 65 students (34 males and 31 females) ranging in age from 10 to 12 in a private secondary school affiliated with the Ministry of Education in Amasya. Two fifth grade classes were randomly chosen. Because of the academic achievement scores of these students were similar to each other, one was assigned as the experimental, and the other as the control group. There were 30 students in the control group and 35 students in the experimental group.

\subsection{Instruments}

\subsubsection{The Reading Comprehension Test}

The reading comprehension test was prepared for the first time as a multiple-choice test. Although there are reading comprehension tests in international literature, these tests were not used in this study since their validity and reliability were not verified for the Turkish language. Similarly, since these tests do not reflect the content of the children's books to be used in this study, the researcher had to structure his own test. First, a multiple-choice test of 60 questions was prepared to assess reading comprehension skills. To ensure the content validity, the reading comprehension test was examined and proofread by three linguists and three child literature experts. Moreover, three developmental experts were consulted to ensure the test items were appropriate to the linguistic and cognitive level of the children. After the expert review, items which were not appropriate for the child's developmental level, not linguistically appropriate, and did not reflect the content of the books were all removed. As a result of these procedures, the test consisting of 46 items and organized for trial practicing was applied to 161 students studying in a secondary school which was not included in the research group. After the practice, item discrimination, item difficulty of all items as well as reliability of the reading comprehension test were calculated. Four items, for which the indices of item discrimination were below .30, were removed from the test. As a result, a reading comprehension test of 42 items was obtained. After item analysis, the coefficient of reliability of the reading comprehension test obtained by KR-20 formula was found to be .91 .

Second, the reading tests, whose validity and reliability were confirmed, were given to the students in the control and experimental group, who were the focus of the research. This test was applied to the students in both groups during the pre-test and the post-test. Throughout the 8-week period, students were expected to respond to all the questions in the test considering books of literary quality that they read previously. Correct responses were given 1 point and wrong responses were given 0 .

\subsubsection{Structured Instruction}

In this study, the experimental and the control group were given two different kinds of instruction. First, the students in the experimental group were instructed about how they were going to use metacognitive strategy in books of literary quality so that they could improve their reading comprehension. This instruction consisted of three parts explaining what to do before, during, and after the reading activity.

Before the reading process, during the planning process of metacognitive strategy, a technique called "Pre-Reading Plan" was used. This technique consists of teacher's questions: (a) The teacher asks students what they know about the text that they are going to read; (b) The teacher wants to check students' foreknowledge by asking them: "Why do you think this way?"; and (c) The teacher then refreshes students' memories by asking them to answer the question: "Now, we have thought over it, do you want to share any kind of information before we start to read?" (Manzo \& Manzo, 1995). This technique was used and enriched with other types of questions that would contribute to the plan: (a) What does the task consist of?, (b) What is its aim?, (c) What kind of information and strategies do I have to have?, and (d) How long will it take and what am I going to make use of (Schraw, 1998).

During the reading process, students were instructed in self-monitoring, which regulates reading comprehension. This 
instruction consisted of 4 main questions: (a) Do I clearly grasp what I am reading?, (b) Does the task mean anything to me?, (c) Am I achieving my goals?, and (d) Do I have to change certain things? (Schraw, 1998). The main goal of these questions is to help students regulate their reading comprehension levels during the reading process. That is to say, during the reading process, students are known to be active thanks to self-monitoring which (a) raises selective attention, (b) helps students estimate how efficient a performance was, and (c) helps students see how useful a learning strategy was (Zimmerman, 1995).

After the reading process, students were asked to answer these questions: (a) What procedures did you follow for completing this task?, (b) What problems did you have during the process?, (c) How can you associate this activity with your prior knowledge?, (d) What was most difficult for you?, (e) What makes you feel confused?, (f) Did you achieve your goal?, (g) What went right?, (h) What went wrong?, and (i) Will you do better next time (Anderson, 2002; Schraw, 1998). Thus, the goal was to improve students' autonomy and self-regulation, which appeared after the reading process thanks to metacognitive strategy, their motivation, self-esteem, self-confidence, and better thinking and learning skills (Ekbatami, 2000; Statman, 1993).

Second, students in the control group were instructed in reading and reading comprehension using the texts found in the 100 Basic Works, which are used in conventional teaching within the Turkish teaching program. During this instruction, no strategies were applied to the students. Only questions concerning the books read, such as "What did you infer from the book?" "What could be the main theme of the book?" "What is the main character of the book doing?", were used.

\subsubsection{Works of Children's Literature}

In this study, students in the experimental group were given children's books of literary quality appropriate for their developmental levels: Long Live the Brotherhood of the Letter Ç (Behiç Ak), Pippi Longs tocking (Astrid Lindgren), The Story of a Seagull and The Cat Who Taught Her To Fly (Luis Sepulveda), Whale and Mandarin (Fazıl Hüsnü Dağlarca), and As Evliya Çelebi (Arslan Sayman). These books were given to the children because they are appropriate in terms of design, content, and didactic elements to the children's linguistic and cognitive levels (Children's and Youth Literature Practice and Research Center, 2016). In addition, these books were chosen both by children's literature criteria and by the remarks of the developmental psychologist. Furthermore, the fact that these books were given national and global awards proves their qualifications. However, students in the control group were given five books, Perili Köşk (Ömer Seyfettin), Yer Altında Bir Şehir (Kemalettin Tuğcu), Pollynanna (Eleanor H. Porter), Gulliver's Travels (Jonathan Swift), and Falaka (Ahmet Rasim), from the 100 Basic Works approved by the Ministry of Education (Ministry of Education, 2005).

\subsection{Data Analysis}

All statistical analyses were performed with Statistical Package for Social Sciences (SPSS), Version 23. A series of independent sample t-test was used to determine whether there was a significant difference between the results of the pre-test and the post-test of the experimental and the control group. In addition, the analysis of covariance (one way Ancova) was used to determine the effect of metacognitive strategy in improving reading comprehension skills by analyzing whether there was a significant difference between the post-intervention scores of the experimental and the control group controling for their pre-test scores (Punch, 2005).

\section{Results}

A series of independent sample t-tests performed to ascertain if there was a significant difference between the experimental and control group in reading comprehension scores before and after intervention. Table 1 reports the results of independent sample t-tests results as well as associated effect sizes as measured by Cohen's $d$.

Table 1. Pre-post results for experimental and control group

\begin{tabular}{|c|c|c|c|c|c|c|c|}
\hline Variable & $\begin{array}{l}\text { Exper. } \\
M\end{array}$ & $S D$ & $\begin{array}{l}\text { Control } \\
M\end{array}$ & $S D$ & $t_{d f}$ & $p$ & $\begin{array}{l}\text { Cohen's } \\
d\end{array}$ \\
\hline $\begin{array}{l}\text { Pre test reading test } \\
\text { Post-test reading test }\end{array}$ & $\begin{array}{l}7.56 \\
14.25\end{array}$ & $\begin{array}{l}2.67 \\
1.95\end{array}$ & $\begin{array}{l}7.20 \\
8.30\end{array}$ & $\begin{array}{l}1.93 \\
1.88\end{array}$ & $\begin{array}{l}.87_{(63)} \\
13.89_{(63)}\end{array}$ & $\begin{array}{l}.389 \\
.001 *\end{array}$ & $\begin{array}{l}.15 \\
3.10\end{array}$ \\
\hline
\end{tabular}

$$
p<.001^{*}
$$

As seen in Table 1, although, there was no significant difference between the experimental and the control group in pre-test reading comprehesion scores ( $t(63)$ : .87, Cohen's $d: .15, p>.05)$, there was a significant difference between the experimental and the control group in post-test reading comprehesion scores $(t(63): 13.89$, Cohen's $d: 3.10, p<.001)$. That is, students in experimental group were significantly higher reading comprehension scores than students in control group. Because, although it is not significant, students in experimental group were slightly higher reading 
comprehension scores than students in control group. Thus, we also conducted a one-way ANCOVA to determine whether post-test scores significantly differ as a function of group membership (experimental or control) controlling for pre-test reading scores. The results presented in Table 2.

Table 2. One Way Ancova Results

\begin{tabular}{llllll}
\hline Source & Type III Sum of Squares & df & Mean Square & F & Sig. \\
\hline Corrected Model & $643.35^{*}$ & 2 & 321.675 & 155.124 & $.000^{*}$ \\
Intercept & 391.19 & 1 & 391.19 & 155.829 & $.000^{*}$ \\
Pre-test & 67.35 & 1 & 67.35 & 29.101 & $.000^{*}$ \\
Experimental Group & 584.31 & 1 & 584.31 & 169.85 & $.000^{*}$ \\
Error & 216.72 & 63 & 3.44 & &
\end{tabular}

$p<.001^{*}$

As seen in Table 2, The One Way Ancova analysis also revealed a significant difference between the pre-test and the post-test in the experimental group that is, using metacognitive strategy in books of literary quality improved the reading comprehension skills of the students in the experimental group when compared to the control group, in which traditional methods were used to attempt to improve reading and comprehension skills.

\section{Discussion}

The results of this study found no significant difference between the experimental and the control group for the pre-test in terms of reading comprehension. However, after the post-test, there was a significant improvement in the reading comprehension of the students reading texts of literary quality by using metacognitive strategy and the students reading five books from the 100 Basic Works in the conventional way. This clearly shows that students should use metacognitive strategy along with books of literary quality to improve reading comprehension skills. Thus, children can both ameliorate their reading skills and become aware of how they can promote comprehension by reading books of literary quality using metacognitive strategy, which fulfills the goal of reading by learning to control the text, i.e., becoming aware of it (Kuhn, 2000).

In this study, it was clear that types of metacognitive awareness such as planning, self-monitoring, self-regulation, and self-evaluation did not emerge in the students attempting to improving reading and reading comprehension by conventional educational means. There are several reasons for this. First, students try to explain the books they read, deprived of any kinds of strategies. This is known to impel students to the processes of lower-order thinking (Facione, 1998). Thus, students have so far been forced to present their opinions about the content of books through a limited frame. Second, these books in the 100 Basic Works continuously prioritize the traditions, customs, and Islamic values of the Turkish culture (Çer, 2015; Kansu-Yetkiner, 2014). Therefore, they were not able to approach the facts in the books critically, creatively, and analytically since their perspectives were stereotyped in an extremely nationalist and Islamic way. This made students passive participants within the reading process. Third, associating characters in these books with non-dynamic, vague, passive, and limited roles (Aslan, 2010; Sever, 2006) caused students in this age range, who are curious, exploring, adventurous, imaginative, playful, creative, sincere, rejecting of advice and command, and excited, to reluctantly read in an affective sense. Therefore, this situation also negatively affected their reading comprehension. The fact that Turkey, in reading comprehension skills was ranked 37th in 2006, 41st in 2009, 42nd 2014, and 41st in 2015 (OECD, 2006, 2010, 2014, 2016) clearly illustrates the negative results of this process because, since 2005, every student has been obliged to read the books in the 100 Basic Works in all primary schools in Turkey (Ministry of Education, 2005).

In the experimental group, students both advanced in reading comprehension skills, such as planning, monitoring, self-regulation, and self-evaluation, through metacognitive strategy and in higher-order thinking skills thanks to children's books. In other words, students using metacognitive strategy in the experimental group rose from comprehension and grasping skills up to the levels of criticizing what they read, evaluating, concluding, estimating, comparing, setting cause and effect relations, and generating original opinions. Such advances are known to contribute to students' improved text comprehension (Lewis \& Smith, 1993). In other words, throughout this process of education, in which students took on higher-order thinking responsibilities, the quality of their relationship with books was more positive and varied as well. Thanks to metacognitive strategy, over an 8-week period, students became qualified readers with behaviors such as questioning, correcting, and note taking, rather just reading in order to finish the book.

This study propounded that children's literature of literary quality should be read through metacognitive strategy. It was found that students had a better comprehension of books throughout the process of reading a qualified book because metacognitive strategy may make the child more active, self-confident, successful, and a participant, taking responsibility for his own planning, self-monitoring, self-evaluation, and self-regulation processes (Baker, 2002). Thus, students can express their emotions and opinions efficiently by increasing their comprehension level. This also 
contributes to the child's social and personal development (Efklides, 2011) because when students can present and understand what they read more efficiently, they become more sociable, self-confident, and successful (Lau \& Chan, 2006).

Above all, the student must first read a book in order to comprehend it. Accomplishing this in a comprehensive manner requires the harmony of motivational, affective, environmental, and physiological variables (Cain, Oakhill, \& Bryant, 2004; Small \& Arnone, 2011). All these variables were found to make positive contributions to reading comprehension in this study. In other words, students affectively approached books with positive feelings while they were motivated to purposefully and eagerly concentrate on the meaning of the text. In terms of the environment, they gained their inner motivation by keeping away from all the variables that would remove them from the text. Thus, the harmony of the variables that provide comprehension could be developed through metacognitive strategy.

This study also revealed the uselessness of conventional reading classes. Conducting reading classes with no strategies for reading the books on the list of the 100 Basic Works cannot improve reading performance. In these classes, since teachers use the question-answer technique, which is deprived of higher-order thinking activity, asking monotonous questions such as "What did you understand? What do you think the main theme of the book could be? What is the main character of the book?" (McCarthy \& Anderson, 2000), the student cannot understand the book and cannot reflect his emotions and opinions properly because according to critical thinking, there is not only one truth but many (Facione, 1998). Thus, conventional reading classes not only make the child passive, but also inhibit him from building a relationship with the book. Therefore, reading classes should be run using metacognitive strategy. In this way, the child could take greater advantage of the books read and perceive them as multi-dimensional.

This study clearly shows the deficiency of not using texts of literary quality in previous studies on metacognitive strategy that aimed to improve reading comprehension skills (Başaran, 2013; Bozkurt \& Memiş, 2013; Çakıroğlu \& Ataman, 2008; Eiles \& Pinkley, 2006; Guthrie et al., 1999; Houtveen \& Grift, 2007; Mert, 2015). The fact that the correlation between books of literary quality that are appropriate for the developmental level of children and metacognitive strategy is significant and it shows the importance of using metacognitive strategy with qualified texts in improving reading comprehension.

The first limitation of this study is that it is uncertain how long the metacognitive skills of students last; therefore, additional monitoring experimental studies should be conducted. Second, this research was performed on only 5 th grade students. For this reason, further studies on different grades should be performed to determine the efficacy of the strategy. Lastly, students only engaged in reading and reading comprehension activities through five works from the 100 Basic Works. The remaining 100 Basic Works could be examined in prospective studies. At the same time, future studies should also investigate different psychological traits, such as attachment styles (Gençoğlu, Topkaya, Şahin, \& Kaya, 2016), as predictors of outcome at the end of study. Mental health problems affect a considerable number of people in Turkey (Topkaya, 2014a, 2014b, 2015a, 2015b; Topkaya \& Meydan, 2013). Thus, improving mental health of these individuals is a key concern for most mental health professionals. One viable way to improve mental health may be reading quality books for children and adolescents. However, this study only focused on students in secondary school and did not exam their current psychological symptoms. Future studies may examine the effects of reading quality books.

Consequently, students were observed to comprehend the text better and higher-order thinking processes emerged in students through metacognitive strategy. Students operated higher-order processes, such as setting cause and effect relationships, comparing, associating, inferring, self-evaluation, and self-regulation, rather than giving short "yes/no" answers for the questions about books of literary quality. Moreover, in the analysis and interpretation of the books they read, they found the relationships among the themes, characters, matters, and conflicts in the books in terms of similarities and differences thanks to reading intertextually. Thus, the students become generating readers rather than passive ones, giving students a participatory role in analyzing the meaning of the text.

\section{Acknowledgments}

E.Ş participated in designing the data collection instruments, performed data collection and analyses, drafted the manuscript. E.C and E.Ş performed data collection, participated in designing the instruments, reviewed and revised the manuscript. E.Ç conceptualized and designed the study, designed the data collection instruments, coordinated and supervised data collection, critically reviewed the manuscript. All authors approved the final manuscript as submitted.

\section{References}

Adams, M. J. (1990). Beginning to read: Thinking and learning about print. Cambridge: MIT Press.

Alexander, P. A., \& Jetton, T. L. (2000). Learning from text: A multidimensional and development perspective. In M. L.

Kamil, P. B. Mosenthal, P. D. Pearson, R. Barr (Eds.). Handbook of reading research (pp.285-310). Mahwah: 
Lawrence Erlbaum Associates Publishers.

Anderson, N. J. (2002). The role of metacognition in second/foreign language teaching and learning. ERIC Digest.Washington: ERIC Clearinghouse on Languages and Linguistics.

Anderson, R. C. (1994). Role of the reader's schema in comprehension, learning, and memory. In R.B. Ruddell, M.R. Ruddell \& H. Singer (Eds.), Theoretical models and processes of reading. (pp. 469-482). Newark, Delaware: International Reading Association.

Arı, G., \& Okur, A. (2013). Öğrencilerin ilköğretim 100 temel eseri okuma durumu [State of students reading 100 basic literary books]. Türkiye Sosyal Araştırmalar Dergisi, 17(3), 307-328.

Aslan, C. (2007a). Yazınsal nitelikli çocuk kitaplarının çocuğun okuduğunu anlama ve yazılı anlatım becerisine etkisi. Eğitim Araştırmaları, 27,15-29.

Aslan, C. (2007b). Yazınsal nitelikli çocuk kitaplarının çocuğun gelişim sürecindeki yeri. II. Ulusal Çocuk ve Gençlik Edebiyatı Sempozyumu (Gelişmeler, Sorunlar ve Çözüm Önerileri). (Yay. Haz.: S. Sever) Ankara Üniversitesi Eğitim Bilimleri Fakültesi Yayını, No: 203, 189-200.

Aslan, C. (2010). An Analysis of the Presentation of Women in 100 Basic Literary Works in Turkey. Eurasian Journal of Educational Research, 38, 19-36.

Baker, L. (2002). Metacognition in comprehension instruction. In Block, C. C. \& Pressley, M. (Eds.), Comprehension Instruction: Research-based best Practices (pp. 77-95). New York: The Guilford Press.

Baker, L., \& Brown, A. L. (1984). Metacognitive skills and reading. In P.D. Pearson (Ed.), Handbook of reading research (pp. 353-394). New York: Longman.

Başaran, M. (2013). 4. Sınıf öğrencilerinin üstbilişsel okuma stratejilerini kullanma durumları ve bu stratejilerle okuduğunu anlama arasındaki ilişki [4th grade students'using metacognitive reading strategies conditions and between the relationship reading comprehension and using these strategies]. Turkish Studies, 8(8), 225-240. http://dx.doi.org/10.7827/TurkishStudies.5502

Benson, P. (2001). Teaching and researching autonomy in language learning. London: Longman.

Boulware-Gooden, R., Carreker, S., Thornhill, A., \& Joshi, R. M. (2007). Instruction of metacognitive strategies enhances reading comprehension and vocabulary achievement of third-grade students. The Reading Teacher, 61(1), 70-77. http://dx.doi.org/10.1598/RT.61.1.7

Bozkurt, M., \& Memiş, A. (2013). Beşinci sınıf öğrencilerinin üstbilişsel okuduğunu anlama farkındalı̆̆ı ve okuma motivasyonları ile okuma düzeyleri arasındaki ilişki [The relationship between 5 th grade elementary school student' metacognitive reading comprehension awareness, reading motivation and reading level]. Ahi Evran Üniversitesi Kırşehir Ĕ̈itim Fakültesi Dergisi, 14(3), 147-160.

Cain, K., Oakhill, J., \& Bryant, P. (2004). Children's reading comprehension ability: Concurrent prediction by working memory, verbal ability, and component skills. Journal of Educational Psychology, 96, 31-42. http://dx.doi.org/10.1037/0022-0663.96.1.31

Cheng, P. W. (1993). Children's reading comprehension reading monitoring: Exploring the relations among attribution, goal/motive, knowledge, process, strategy, and reading performance. Unpublished Doctoral thesis. Alberta: University of Alberta.

Children Foundation (2009). 100 Temel Eser Raporu [The Report of 100 Basic Works]. Accessed March 29, 2016, from http://www.cocukvakfi.org.tr/rapor/100temeleser.pdf

Children's and Youth Literature Practice and Research Center (2016). İlköğretim döneminde çocuklara seslenen yapıtlar [Primary schools appropriate children's books]. Accessed April 04, 2016, from http://cogem.ankara.edu.tr/

Christensen, L. B. (2004). Experimental methodology. United States of America: Pearson Education.

Çakıroğlu, A., \& Ataman, A. (2008). Üstbilişsel strateji öğretiminin okuduğunu anlama başarı düzeyi düşük öğrencilerde erişi artırımına etkisi [The effect of metacognitive strategy training on improving the achievement level of students having low achievement levels of reading comprehension]. Sakarya Üniversitesi Eğitim Fakültesi Dergisi, 16, 1-13.

Çer, E. (2015). One step forward and two steps back: A study of the image of woman in the 100 basic works of literature in Turkey. Universal Journal of Educational Research, 3(12), 1008-1014.

http://dx.doi.org/10.13189/ujer.2015.031209

Çer, E. (2016a). Çocuk edebiyatı: 0-6 yaş çocuk kitaplarında çocuk gerçekliği ve çocuğa görelik. Ankara: Eğiten Kitap. 
Çer, E. (2016b). Preparing for books children from birth to six: The approach of appropriateness for the child. Journal of Education and Practice, 7(6), 78-99.

Çer, E. (2016c). Preparing for books children from birth through six: A new children's reality approach.Universal Journal of Educational Research, 4(5), 1024-1036. http://dx.doi.org/10.13189/ujer.2016.040512

Davidson, B. (1994). Critical thinking: A perspective and prescriptions for language teachers. The Language Teacher, $18(4), 20-26$.

Day, J. D., \& Zajakowski, A. (1991). Comparisons of learning ease and transfer propensity in poor and average readers. Journal of Learning Disabilities, 24, 421-426. http://dx.doi.org/10.1177/002221949102400707

Dickinson, D., \& Porche, M. (2011). Relation between language experiences in preschool classrooms and children's kindergarten and fourth-grade language and reading abilities. Child development, 82(3), 870-886. http://dx.doi.org/10.1111/j.1467-8624.2011.01576.x

Dilidüzgün, S. (2004). Çağdaş çocuk yazını. İstanbul: Morpa.

Dilidüzgün, S. (2006). Eğitim Gerçeği Açısından 100 Temel Eser Tartışmaları. Varlık, 112(479), 23-26.

Dole, J. A., Brown, K. J., \& Trathen, W. (1996). The effects of strategy instruction on the comprehension performance of at-risk students. Reading Research Quarterly,31, 62-88. http://dx.doi.org/10.1598/RRQ.31.1.4

Dutta, S. (1994). Predicting as a pre-reading activity. English Teaching Forum, 32(1), 39-41.

Efklides, A. (2011). Interactions of metacognition with motivation and affect in self-regulated learning: The MASRL model. Educational Psychologist, 46, 6-25. http://dx.doi.org/10.1080/00461520.2011.538645

Eilers, L. H., \& Pinkley, C. (2006). Metacognitive strategies help students to comprehend all text. ReadingImprovement, 43(1), 13-29.

Ekbatani, G. (2000). Moving toward Learner-Directed Assessment. In G. Ekbatani and H. Pierson (Eds.), Learner-Directed Assessment in ESL (pp. 1-11). New Jersey: Mahwah.

Facione, P. A. (1998). Critical thinking: What it is and what it counts?, California: California Academic Press.

Gençoğlu, C., Topkaya, N., Şahin, E., \& Kaya, L. (2016). Attachment styles as predictors of stigma tendency in adults. Educational Process: International Journal, 5(1), 7-21. http://dx.doi.org/10.12973/edupij.2016.51.1

Goswami, U., \& Bryant, P. (1990). Phonological skills and learning to read. Hove: Lawrence Erlbaum Associates.

Guthrie, J. T., Wigfield, A., Metsala, J. L., \& Cox, K. E. (1999). Motivational and cognitive predictors of text comprehension and reading amount. Scientific Studies of Reading, 3, 231-256. http://dx.doi.org/10.1207/s1532799xssr0303_3

Guthrie, J. G., \& Wigfield, A. (2000). Engagement and motivation in reading. In M.L. Kamil, P.B. Mobenthal, P.D. Pearson \& R. Barr (Eds.). Handbook of reading research, 3(pp. 403-420). New York: Longman.

Houtveen, A. M., \& van de Grift, W. M. (2007). Effects of metacognitive strategy instruction and instruction time on reading comprehension. School Effectiveness and School Improvement, 18(2), 173-190. http://dx.doi.org/10.1080/09243450601058717

İşcan, A., Arıkan, İ. B., \& Küçükaydın, M. A. (2013). İlköğretim ikinci kademe öğrencilerin kitap okuma alışkanlıkları ve okumaya ilişkin tutumları [Reading habits and reading the secondary school students' attitudes on]. Uluslararası Avrasya Sosyal Bilimler Dergisi, 4(11), 1-16.

Kansu-Yetkiner, N. (2014). Words Apart, Worlds Apart: Peritexts from Islamized Translations of World Classics in Children's Literature. Children's Literature in Education, 45(4), 340-353. http://dx.doi.org/10.1007/s10583-014-9218-y

Köksal, K., \& Değirmenci, H. (2015). İlköğretim okullarında uygulanan okuma saatlerinin değerlendirilmesine ilişkin öğretmen görüşleri [Teacher opinions for the evaluation of reading hours in the elementary schools]. Türkiye Sosyal Araştırmalar, 19(2), 11-28.

Kuhn, D. (2000). Metacognitive development. Current Directions in Psychological Science, 9, 178-181. http://dx.doi.org/10.1111/1467-8721.00088

Lau, K. L., \& Chan, D. W. (2006). Reading strategy use and motivation among Chinese good and poor readers in Hong Kong. Journal of Research in Reading, 26(2), 177-190. http://dx.doi.org/10.1111/1467-9817.00195

Leppanen, U., Aunola, K., \& Nurmi, J. E. (2005). Beginning readers' reading performance and reading habits. Journal of Research in Reading, 28(4). 383-399. http://dx.doi.org/10.1111/j.1467-9817.2005.00281.x 
Lewis, A., \& Smith, D. (1993). Defining higher order thinking. Theory Into Practice, 32(3), 131-137. http://dx.doi.org/10.1080/00405849309543588

Long, D. L., Seely, M. R., Oppy, B. J., \& Golding, J. M. (1996). The role of inferential processing in reading ability. In B.K. Britton and A.C. Graesser (Eds.). Models of understanding text, (pp. 189-212). Mahwah: Lawrence Erlbaum Associates.

Lukens, R. J., Smith, J. J., \& Coffel, C. M. (2013). A critical handbok of children's lirerature. New York: Pearson Education.

Manzo, A., \&Manzo, U. (1995). Teaching Children to Be Literate: A Reflective Approach. USA: Holt Rinehart and Winston.

McCarthy, J. P., \& Anderson, L. (2000). Active learning techniques versus traditional teaching styles: Two experiments from history and political science. Innovative Higher Education, 24(4), 279-294. http://dx.doi.org/10.1023/B:IHIE.0000047415.48495.05

Meneghetti, C., Carretti, B., \& De Beni, R. (2006). Components of reading comprehension and scholastic achievement. Learning and Individual Differences, 16, 291-301. http://dx.doi.org/10.1016/j.lindif.2006.11.001

Mert, E. L. (2015). Türkçe öğretmen adaylarının okuma stratejilerine ilişkin bilişsel farkındalık düzeyleri [Metacognitive awareness level of candidate Turkish teachers in reading strategies]. Erzincan Üniversitesi Sosyal Bilimler Enstitüsü Dergisi, ÖS-II, 95-106.

Ministry of Education (2005). 100 temel eser'in tam listesi [The complete list of 100 essential readings]. Ankara: Ministry of Education, Republic of Turkey. Accessed March 29, 2016, from http://www.meb.gov.tr/haberler/haberayrinti.asp?ID=5924.

Ministry of Education (2008). Türkiye okuyor kampanyası [Turkey is reading campaign]. Accessed March 29, 2016, from http://ankara.meb.gov.tr/

Neuman, S. B., \& Wright, T. (2007). Reading to your child. New York: Scholastic.

O’Malley, J. M., \& Chamot, A. U. (1990). Learning strategies in second language acquisition. Cambridge: Cambridge University Press.http://dx.doi.org/10.1017/CBO9781139524490

OECD (2006). PISA 2006 Results: Science competencies for tomorrow's world (Volume I). OECD Publishing.

OECD (2010). PISA 2009 Results: What students know and can do: Student performance in reading, mathematics and science (Volume I). OECD Publishing.

OECD (2014). PISA 2012 Results: What students know and can do - Student performance in mathematics, reading and science (Volume I). OECD Publishing.

OECD (2016). PISA 2015 Results. Accessed March 29, 2016, from http://www.oecd.org/dataoecd

Pressley, M., \& Afferbach, P. (1995). Verbal protocols of reading: The nature of constructively responsive reading. Routledge.

Punch, K. F. (2005). Sosyal araştırmalara giriş: Nicel ve nitel yaklaşımlar. Ankara: Siyasal.

Russell, D. L. (2009). Literature for Children, A Short Introduction. New York: Pearson Education.

Sawyer, W. E. (2012). Growing up with Literature. Abbany: Wadsworth.

Saxby, M. (2007). Books in the life of a child: Bridges to literature and learning. Australia: Macmillan Publishers.

Schraw, G. (1998). Promoting general metacognitive awareness. Instructional Science, 26(1-2), 113-125. http://dx.doi.org/10.1023/A:1003044231033

Schunk, D. (1997). Self-monitoring as a motivator during instruction with elementary school students. ERIC Document No. ED 404035.

Senechal, M., LeFevre, J. A., Hudson, E., \& Lawson, E. P. (1996). Knowledge of storybooks as a predictor of young children's vocabulary. Journal of Educational Psychology, 88(3), 520-536. http://dx.doi.org/10.1037/0022-0663.88.3.520

Sever, S. (2006). Türkçe Öğretiminin Çözülemeyen Sorunları, Varlık, 1189, 8-16.

Sever, S. (2008). Çocuk ve edebiyat. İzmir: Tudem.

Small, R. V., \& Arnone, M. P. (2011). Creative reading. Knowledge Quest, 39(4), 12-15.

Spear-Swerling, L., Brucker, P. O., \& Alfano, M. P. (2010). Relationships between sixth-graders' reading 
comprehension and two different measures of print exposure. Reading and Writing: An Interdisciplinary Journal, 23, 73-96. http://dx.doi.org/10.1007/s11145-008-9152-8

Statman, D. (1993). Self-assessment, self-esteem and self-acceptance. Journal of Moral Education, $22,55-62$. http://dx.doi.org/10.1080/0305724930220106

Staton, J. (1984). Thinking together: Language interaction in children's reasoning. In C. Thaiss, \& C. Suhor (Eds.), Speaking and writing, K-12: Classroom strategies and the new research (pp. 144-187). Urbana: National Council of Teachers of English.

Stevens, R. J. (1988). Effects of strategy training on the identification of the main idea of expository passages. Journal of Educational Psychology, 80, 21-26. http://dx.doi.org/10.1037/0022-0663.80.1.21

Sweet, A. P., \& Snow, C. (2002). Reconceptualizing reading comprehension. In C. C. Block, L. B. Gambrell, M. Pressley (Eds.), Improving comprehension instruction (pp. 17-53). San Francisco: Jossey-Bass.

Şahin, E., \& Topkaya, N. (2015). Factor structure of the Social Appearance Anxiety Scale in Turkish early adolescents. Universal Journal of Educational Research, 3(8), 513-519.http://dx.doi.org/10.13189/ujer.2015.030806

Şahin, E., Barut, Y., \& Ersanl1, E. (2013). Parental education level positively affects self-esteem of Turkish adolescents. Journal of Education and Practice, 4(20), 87-97.

Şahin, E., Barut, Y., \& Ersanl1, E. (2013). Sociodemographic variables in relation to social appearance anxiety in adolescents. The International Journal of Social Sciences, 15(1), 56-63.

Şahin, E., Barut, Y., Ersanlı, E., \& Kumcağı, H. (2014). Self-esteem and social appearance anxiety: An investigation of secondary school students. Journal of Basic and Applied Scientific Research, 4(3), 152-159.

Şahin, E., Ersanlı, E., Kumcağız, H., Barut, Y., \& Ak, E. (2014). Sociodemographic differences in empathic tendency: A Sample of Religious High School Students. Journal of Studies in Education, 4(4), 1-11. http://doi.org/10.5296/jse.v4i4.6216

Tan, A., \& Nicholson, T. (1998). Flashcards revised: Training poor readers to read words faster improves their comprehension of text. Journal of Educational Psychology, 89, 276-288. http://dx.doi.org/10.1037/0022-0663.89.2.276

Topkaya, N. (2014a). Psikolojik yardim alma niyetini yordamada demografik, bireysel ve çevresel faktörler. Türk Psikoloji Dergisi, 29(74), 1-11.

Topkaya, N. (2014b). Gender, self-stigma, and public stigma in predicting attitudes toward psychological help-seeking. Educational Sciences: Theory \& Practice, 14(2), 10-17.

Topkaya, N. (2015a). Factors influencing psychological help seeking in adults: A Qualitative Study. Educational Sciences: Theory \& Practice, 15(1), 21-31. http://dx.doi.org/10.12738/estp.2015.1.2094

Topkaya, N. (2015b). Willingness to seek psychological help among turkish adults. Revista de Cercetare Si Interventie Sociala, 48, 149-163.

Topkaya, N., \& Meydan, B. (2013). Üniversite öğrencilerinin problem yaşadıkları alanlar, yardım kaynakları ve psikolojik yardım alma niyetleri. Trakya Üniversitesi Ĕ̌itim Fakültesi Dergisi, 3(1), 25-37.

Veenman, M. V., Van Hout-Wolters, B., H., \& Afflerbach, P. (2006). Metacognition and learning: conceptual and methodological considerations. Metacognition Learning, 1, 3-14. http://dx.doi.org/10.1007/s11409-006-6893-0

Wang, A. Y. (2011). Exploring the relationship of creative thinking to reading and writing. Thinking Skills and Creativity, 7, 38-47.

Zimmerman, B. (1995). Dimensions of academic self-regulation: A conceptual framework for education. In B. J. Zimmerman and D. H. Schunk (Eds.), Self-Regulation of Learning and Performance (pp. 3-24). Hillsdale: Lawrence Erlbaum.

This work is licensed under a Creative Commons Attribution 3.0 License. 